\title{
A economia do Verbo encarnado o 0 diálogo entre as religiōes em Claude Geffré
}

Recebido: 11/08/2016. Aprovado: 31/08/2016.

\section{Tiago de Fraga Gomes*}

Resumo: A economia do Verbo encarnado, como sacramento de uma economia mais vasta, é um elemento cristológico relevante para fundamentar o diálogo entre as diferentes tradições religiosas. Segundo Claude Geffré, nenhuma religião em sua contingência histórica pode ser uma tradução adequada da plenitude inexprimível do mistério divino. A teologia tem a missão de reinterpretar a unicidade do cristianismo como religião de salvação entre as religiões do mundo, superando todo triunfalismo soteriológico. Interrogar-se a respeito da pluralidade das expressões religiosas, em sua alteridade irredutivel, no interior do único desígnio divino universal, requer uma postura de respeito pela experiência do outro e de sinceridade na busca da verdade. Somos crentes, porém, não somos proprietários de Deus e da sua revelação.

Palavras-chave: Alteridade. Cristologia. Diálogo. Pluralismo. Religiões. Revelação.

Abstract: The economy of the Incarnate Word, as sacrament of the broader economy, is a Christological element relevant to support dialogue between different religious traditions. According to Claude Geffré, no religion in its historical contingency may be an appropriate translation of the inexpressible fullness of the divine mystery. Theology has the task of reinterpreting the uniqueness of Christianity as a religion of salvation among the religions of the world, surpassing all soteriological triumphalism. Questioning about the plurality of religious expressions in its irreducible otherness, within the single universal divine plan, requires an attitude of respect for the experience of others and sincerity in the pursuit of truth. We are believers, yes, but not owners of God and his revelation.

Keywords: Otherness. Christology. Dialogue. Pluralism. Religions. Revelation.

* Doutorando em Teologia pela PUCRS, bolsista CAPES. Mestre em Teologia pela PUCRS (2015). Bacharel em Teologia pela PUCRS (2012). Bacharel em Filosofia pela PUCRS (2007). Presbítero da Diocese de Osório, RS. 


\section{Introdução}

A presente pesquisa pretende trabalhar o tema da economia do Verbo encarnado como espaço cristológico de diálogo entre as religiões. Queremos buscar no próprio centro da fé cristã os motivos que nos impelem à busca da Verdade através do encontro com a verdade do outro. Para Claude Geffré, "nenhuma manifestação histórica de Deus, mesmo o acontecimento Jesus de Nazaré, pode ser tida como absoluta."' Isto nos leva a entender que nenhuma religião pode ser uma tradução adequada da plenitude inexprimível do mistério divino. A consciência de sua contingência histórica faz as religiões, inclusive o cristianismo, buscarem, através do diálogo, aqueles lampejos de verdade que iluminam todas as pessoas. Mesmo a unicidade singular de Cristo não pode ser interpretada em termos de excelência e de integração. O paradoxo da encarnação como a manifestação do Absoluto em uma realidade relativa, faz-nos compreender que o mistério divino ultrapassa os nossos conceitos limitados e circunscritos e as nossas experiências particulares, fazendo-nos ir ao encontro do outro, no anseio de plenitude, procurando uma verdade mais ampla.

Todo verdadeiro diálogo deve promover uma igualdade de dignidade na diferença de identidades, com o intuito de celebrar uma verdade mais profunda que as verdades parciais dos interlocutores individualmente. O diálogo ajuda a superar toda pretensão insustentável de totalização monopolizadora da verdade. Jesus nos revela um Deus que é "comunhão na diferença" ", como mistério de comunicação que é saída de si ao encontro do outro, suscitando a diversidade. O cultivo de uma imaginação analógica "que desvela uma semelhança na diferença"3, ajuda a escapar do equívoco sem cair no unívoco. É fundamental respeitar o outro, porém, sem deixar de ser fiel à própria identidade. "O resultado deste diálogo é descobrir que há um além do diálogo, a saber, a transformação de cada um dos interlocutores. Eu sou mudado na maneira de apropriar-me de minha própria fé quando sou confrontado com a verdade do outro." ${ }^{4} \mathrm{O}$ diálogo leva a relativizar a maneira como possuímos a própria verdade e conduz a uma interpretação nova das próprias tradições.

\footnotetext{
1 GEFFRÉ, Claude. De Babel a Pentecostes, p. 74.

2 Id. Ibid., p. 202.

3 Id. Crer e interpretar, p. 144.

4 Id. Ibid., p. 146.
} 
Verdades diferentes não são necessariamente inimigas ou contraditórias, mas podem ser companheiras ou complementares para responder aos inúmeros questionamentos existenciais que assolam a razão humana. Vamos começar trabalhando a questão da economia da revelação diante do fenômeno do pluralismo religioso atual. Em seguida, trataremos da questão da economia do Verbo encarnado como sacramento de uma economia mais vasta, para por fim, abordar o tema do diálogo entre as religiões na perspectiva da alteridade irredutível.

\section{A economia da revelação diante do pluralismo religioso hodierno}

$\mathrm{Na}$ economia da revelação de Deus na história, muitas vezes não se levou a sério "a alteridade das outras religiões na sua diferença irredutível"s, como foi o caso da teologia do acabamento 6 , a qual via as outras religiões apenas como preparações evangélicas "da única verdadeira religião revelada, que é o cristianismo." Nessa concepção, os não cristãos estariam ordenados ao povo de Deus, e tudo o que de bom e verdadeiro se encontra neles, seriam elementos que na religião cristã encontrariam o seu acabamento e a sua plenitude. O Concílio Vaticano II dá um passo significativo com a Nostra Aetate no que diz respeito às outras religiões, afirmando que a Igreja nada rejeita do que há de verdadeiro e santo nelas, pois "considera com sincero respeito esses modos de agir e viver, esses preceitos e doutrinas, que, embora em muitos pontos difiram do que ela mesma crê e propõe, não raro refletem um raio daquela Verdade que ilumina todos os homens" (NA 2). Passados mais

5 Id. De Babel a Pentecostes, p. 48.

6 Segundo Faustino Teixeira, duas posições se destacam no que diz respeito à teoria ou teologia do acabamento. À primeira posição se relacionam os teólogos J. Daniélou, $\mathrm{H}$. de Lubac, $\mathrm{H}$. Urs von Balthasar etc., segundo os quais "os valores positivos das religiões não-cristãs são explicitamente reconhecidos, mas destinados a encontrar o seu 'acabamento' (remate) no cristianismo" (TEIXEIRA, Faustino. Teologia das religiões, p. 45-46), como se essas religiões pedagogicamente fossem preparações ao Evangelho. Uma segunda posição, associada principalmente ao cristianismo anônimo de K. Rahner, pode ser definida como uma teologia que reconhece a presença de Cristo nas outras religiões. Segundo essa posição, "as diversas tradições religiosas da humanidade são portadoras de valores soteriológicos positivos para os seus membros, pois nelas e através delas manifesta-se a presença operativa de Jesus Cristo e de seu mistério salvífico." (Id. Ibid., p. 47). Nesse sentido, todas as religiões teriam um relacionamento anônimo e atemático com Cristo.

7 GEFFRÉ, Claude. op. cit., p. 46. 
de cinquenta anos, a teologia católica ainda está tirando as implicações teológicas dessa afirmação.

Apesar de julgar positivamente as religiões não cristãs, reconhecendo que elas podem ser portadoras de valores salutares, o Concílio Vaticano II não chegou a considerá-las como vias de salvação. A teologia atual, a partir da consideração da "pluralidade das vias para Deus" , busca aprofundar o significado soteriológico do pluralismo religioso ${ }^{9}$, buscando uma reinterpretação de nossa visão do plano salvífico de Deus. Vários teólogos se interrogam se um pluralismo de fato nos remeteria a um pluralismo de princípio, o qual estaria inserido no interior do misterioso desígnio de Deus. Outra questão que se impõe se refere à necessidade de ultrapassarmos a nossa visão linear da economia da salvação, buscando "uma história ontológica que não começa nem com Abraão, nem mesmo com Adão, mas com o mistério de Cristo que é a plenitude dos tempos" ${ }^{10}$ e se manifesta na pluralidade das culturas e religiões.

Atualmente há uma consciência mais aguda de que o pluralismo religioso é uma questão insuperável devida à "relatividade histórica das religiões" "11, inclusive do cristianismo, apesar de estarem em busca do Absoluto. Impõe-se a problemática a respeito do "significado da pluralidade das religiões no único desígnio de Deus." ${ }^{2}$ É possível desnudar o cristianismo de certa pretensão absolutista sem enveredar para um relativismo doutrinal ou para um indiferentismo prático. Porém, é necessário viver um engajamento forte em relação à mensagem cristã, sem por isso, alimentar uma postura imperialista ou exclusivista na relação com outras tradições religiosas. A unicidade e a singularidade da mediação de Cristo

$8 \quad$ Id. Ibid., p. 49.

9 Segundo Roberlei Panasiewicz, vive-se atualmente o fenômeno do pluralismo em todos os níveis da sociedade, inclusive na religião. "Cabe às religiões tradicionais confrontarem-se com o novo desafio e com a nova forma de pluralismo, o religioso. Com o fenômeno do pluralismo religioso, o desafio para as tradições religiosas e, de modo particular, para o cristianismo - que imperou durante séculos no mundo ocidental -, fica mais agudo do que com o da secularização." (PANASIEWICZ, Roberlei. Diálogo e revelação, p. 36-37). Graças às redes de comunicação global, temos cada vez mais um conhecimento aprofundado das diversas culturas e religiões da humanidade, e, concomitantemente, uma consciência mais aguda da relatividade histórica das mesmas. O pluralismo religioso manifesta mais claramente o aspecto da transcendência de Deus que não se deixa prender aos limites de nenhuma figura historicamente determinada.

10 GEFFRÉ, Claude. op. cit., p. 50.

11 Id. Ibid., p. 63.

12 Id. Ibid., p. 64. 
não excluem, nem mesmo totalizam o valor salutar das outras religiões, o que reforça a dimensão dialógica da religião cristã.

Deus se revela para salvar, e a história da salvação não se restringe à economia judaico-cristã. A salvação de Deus não está restrita a uma religião em particular, sua ação excede os limites visíveis e compreensíveis das instituições culturais e religiosas. "Deus quer a salvação e a felicidade de todos os homens." "13 Essa salvação é veiculada por meios limitados, os quais são sacramentais de uma graça abundante e misteriosa que não faz distinção de pessoas. A salvação está no mundo para além das Igrejas, pois estas são instrumentos da graça divina salvadora que penetra o universo e cala fundo no coração humano. Segundo Geffré, é uma virtude estarmos atentos para o fato de que "as Igrejas, mas também as religiões, não são, elas mesmas, a salvação, mas sacramento da salvação, isto é, da presença salvífica, silenciosa, mas atuante, de Deus, que conduz a criação ao seu acabamento pela intermediação das liberdades humanas." ${ }^{14}$ A missão das religiões é ser um instrumento do divino.

Para Geffré, há em primeiro lugar uma história geral da salvação, coextensiva à história do mundo, e uma história da revelação como segundo momento que se desenrola desde o primeiro. A proto-história da criação é a condição de possibilidade para a deutero-história da revelação. Não são duas histórias separadas, mas a mesma história, compreendida em dois momentos pedagogicamente estipulados, para entendermos que a revelação acontece dentro da dinâmica histórica e excede nossos esquemas mentais situados em contextos muito específicos. Karl Rahner distingue uma revelação transcendental, que coincide com a história do espírito criado, de uma revelação categorial, temática, específica das culturas e religiões.

Duas perícopes bíblicas nos ajudam a compreendermos melhor a dinâmica da revelação de Deus diante do pluralismo religioso hodierno: Babel e Pentecostes. Babel é o símbolo da ambição idolátrica de uma humanidade monolítica que quer substituir o único Deus. Babel representa o desejo de poder e de uniformidade. Já Pentecostes representa o encontro na pluralidade. Em Pentecostes, a pluralidade das línguas e das culturas é sinal da ação do Espírito Santo. "Com a efusão do Espírito do Ressuscitado, em Pentecostes, é permitido pensar que a pluralidade das

\footnotetext{
13 Id. Ibid., p. 65.

14 Id. Ibid., p. 66.
} 
línguas e das culturas é necessária para traduzir a riqueza multiforme do Mistério de Deus." ${ }^{15}$ Deus cria o ser humano plural como homem e mulher, e o chama a viver em comunidade, em relação. Deus abençoa o múltiplo. Isso nos faz pensar em uma pluralidade de economias da salvação numa "história da salvação diferenciada" 16 , que prescinde de uma conceituação cronológica, ousando preconizar uma história ontológica que tem em Cristo o arquétipo primordial da humanidade.

Segundo Geffré, a pedagogia divina na economia da revelação judaico-cristã, caminha dos pactos abraâmico e mosaico, para um universalismo cristológico. É possível perceber uma universalidade cada vez mais explícita, em detrimento de um exclusivismo, restrito a alguns poucos beneficiários da Aliança, cada vez menos enfatizado. Jesus elogia a atitude dos estrangeiros que dão lição de fé a muitos em Israel $(M t 8,10$; Lc 17,18). A ideia de uma revelação geral e universal que se particulariza em uma "economia diversificada" 17 , abre nossos olhos para o fato de que a história da salvação ultrapassa os limites de Israel e das Igrejas cristãs. Para Geffré, essa história salvífica "coincide com a história espiritual da humanidade." ${ }^{18}$ Conceber a revelação em sua natureza diversificada, não compromete em nada a singularidade da mediação de Cristo, antes, pelo contrário, ajuda a interpretá-la de maneira mais ampla e plural, em consonância com o desígnio de Deus, o qual pode ser melhor compreendido a partir da soma das verdades religiosas do que em sua divisão e isolamento.

Mesmo sendo Jesus Cristo realmente, para a fé cristã, a revelação decisiva e definitiva sobre Deus, não podemos pretender que o cristianismo tenha o monopólio da verdade religiosa sobre Deus e sobre as relações com Deus. Há, nas outras religiões, experiências religiosas autênticas que não foram, e não serão tematizadas ou postas em prática no interior do cristianismo pelo fato mesmo de sua particularidade histórica. [...] Deve-se reconhecê-las na sua diferença, em vez de reconhecer nelas valores implicitamente cristãos. ${ }^{19}$

\footnotetext{
15 Id. Ibid., p. 67.

16 Id. Ibid., p. 68.

17 Id. Ibid., p. 69.

18 Id. Ibid., p. 70.

19 Id. Ibid., p. 71-72.
} 
A plenitude da revelação de Deus e o próprio acontecimento Jesus Cristo não estão circunscritos exclusivamente à letra do Novo Testamento. Além disso, não podemos nos contentar com uma concepção cronológica e linear da história da salvação, esquecendo a sua dimensão escatológica. A pluralidade das religiões como manifestação da riqueza multiforme do mistério divino, é a expressão do desígnio soteriológico universal de Deus para toda a humanidade. É importante tomar consciência disso prescindindo de todo absolutismo exclusivista, porém, sem cair em um relativismo indiferente. Pode nos ajudar, nesse sentido, voltar ao centro mesmo da fé cristã, adentrando no mistério da "irrupção de Deus na particularidade histórica de Jesus de Nazaré"20, que paradoxalmente identifica em si mesmo a concretude imanente e a universalidade transcendente.

Para Geffré, cada experiência religiosa autêntica, seja ela orante, axiológica ou contemplativa, é misteriosamente sustentada pelo Espírito Santo. Por isso, "é na prática de suas próprias tradições religiosas que os membros das outras religiões respondem positivamente à oferta de salvação de Deus." ${ }^{21}$ Conscientes das ambiguidades e contradições existentes em muitas religiões, é necessário "praticar um discernimento crítico" 22 que ajude a avaliar no interior de cada religião quais dos seus elementos constitutivos "favorecem a abertura para o Absoluto e a prática da justiça no sentido do Reino de Deus que nos foi revelado em Jesus Cristo." ${ }^{23}$ Nesse sentido, podemos entender as religiões como partícipes de uma vasta economia da salvação, e que as pessoas podem ser salvas $n a$ e através de sua pertença a determinada tradição religiosa.

Toda forma religiosa que favorece a descentralização do homem em prol de um maior do que ele mesmo e em prol do outro constitui um germe em relação com o mistério da salvação. Esses germes podem ser da ordem do conhecimento, na medida em que certas tradições religiosas se apoiam em Escrituras sagradas que favorecem a busca do verdadeiro Deus. Eles podem ser da ordem do culto: há ritos, sacrifícios, práticas ascéticas da alma e do corpo que são como que um princípio da verdade do relacionamento religioso entre o homem e Deus. Eles podem ser de ordem ética: há em algumas religiões exigências de esquecimento de si,

\footnotetext{
20 Id. Ibid., p. 74.

21 Id. Ibid., p. 77.

22 Id. loc. cit.

23 Id. loc. cit.
} 
de justiça, de compaixão, de serviço fraterno e de hospitalidade que são como que sementes evangélicas, isto é, valores do Reino já inaugurado por Cristo. ${ }^{24}$

Os homens e as mulheres de boa vontade e de coração sincero contribuem a seu modo para o advento do Reinado de Deus. Cada figura religiosa contém algo de irredutível que não pode ser integrado no cristianismo histórico. Além disso, a consciência da ausência original25 que dá fundamento à fé cristã "é a condição de uma aproximação com o outro, com o estrangeiro, com o diferente." 26 A dimensão quenótica do cristianismo é o fundamento cristológico para o caráter não imperialista e relacional do cristianismo em relação às outras religiões. A singularidade cristã no concerto das religiões do mundo não está no fato de ser exclusiva ou inclusiva de outras experiências, mas em ser "sinal daquilo que lhe falta"27, como relação, que não fragmenta ou divide, mas que une mantendo a diversidade na alteridade, no respeito e na reverência mútuas. O cristianismo histórico como religião não absoluta, testemunha a revelação de forma a não esgotar a riqueza presente nas outras tradições religiosas. Cristo mesmo não se esgota no cristianismo. A economia do Verbo encarnado, como paradoxo do Logos feito carne28, nos ajuda a entender a dinâmica da revelação universal de Deus na história multicultural e plurirreligiosa da humanidade.

\section{A economia do Verbo encarnado como sacramento de uma economia mais vasta}

Segundo Geffré, “o fundamento teológico do pluralismo religioso e, portanto, do diálogo inter-religioso, depende do fato de que a economia do Verbo encarnado é o sacramento de uma economia mais vasta, que

24 Id. Ibid., p. 78.

25 Segundo Geffré, à luz de uma teologia da cruz, podemos compreender o cristianismo não como uma totalidade fechada, mas como relação, como diálogo, e mesmo como falta. "É o túmulo vazio, a ausência do fundador que foi o advento do corpo da comunidade cristã primitiva e do corpo das Escrituras." (Id. Ibid., p. 83-84). Id. Ibid., p. 84.

27 Id. loc. cit.

28 O paradoxo do Logos feito carne "não decorre de uma contradição lógica, mas do fato de um acontecimento que transcende todas as expectativas e possibilidades humanas." (Id. Ibid., p. 92). O paradoxo diz respeito à união do Logos eterno de Deus com a carne histórica e temporal humana na pessoa de Cristo, concebido como absolutamente concreto e absolutamente universal. 
coincide com a história religiosa da humanidade. ${ }^{\prime 29} \mathrm{Ou}$ seja, a revelação histórica de Jesus de Nazaré seria o sacramento de uma revelação transcendental "coextensiva à história humana." ${ }^{30}$ Nessa perspectiva, a história humana, lugar da revelação de Deus, é fecundada desde as suas origens com as sementes do Verbo e os dons do Espírito Santo. "A história universal é ao mesmo tempo a história da busca do homem pelo Absoluto, a que chamamos de Deus, e da busca do homem por Deus." 31 Nesse sentido, Duquoc afirma que as religiões "são caminhos autênticos na busca do divino" 32 , e a disseminação legítima das religiões segue uma dinâmica misteriosa que requer uma abertura teológica para o diálogo.

Desde a origem, o Desígnio criador de Deus é um Desígnio de salvação em Jesus Cristo. Basta, para isso, reportar-nos ao capitulo primeiro da epistola aos Colossenses. Apesar de seus erros e de suas imperfeições, as múltiplas expressões do fenômeno religioso concorrem, à sua maneira, para uma melhor manifestação da plenitude inesgotável do Mistério de Deus. Como Schillebeeckx gostava de dizer, Deus não cessa de se narrar na história. Em vez do axioma "Fora da Igreja não há salvação", melhor seria dizer: "Fora do mundo não há salvação". E no seu discurso aos cardeais que acompanharam o encontro de Assis, em outubro de 1986, João Paulo II declarou que o engajamento no diálogo inter-religioso recomendado pelo concílio só se justifica se as diferenças religiosas não forem necessariamente redutoras do Designio de Deus. E acrescentou que essas diferenças "são menos importantes do que a unicidade desse designio". ${ }^{33}$

A teologia cristã das religiões tem a difícil tarefa de conciliar a multiplicidade das vias para Deus sem que isso comprometa a unicidade da mediação de Cristo, o qual é o próprio Deus que veio habitar entre os homens. Prescindindo de toda tentação de sacrificar a universalidade salvífica de Cristo, "é antes o aprofundamento do paradoxo da encarnação que nos permite respeitar o valor irredutível das outras religiões sem em nada sacrificar a unicidade do mistério de Cristo." ${ }^{34}$ Os teólogos americanos Paul Knitter e Roger Haight, por exemplo, sacrificam "um

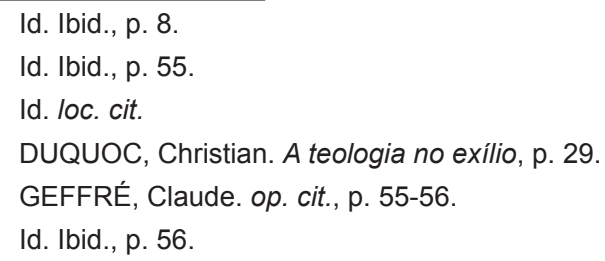


cristocentrismo inclusivo em prol de um teocentrismo radical, segundo o qual todas as religiões, inclusive o cristianismo, giram em torno deste sol que é o Mistério de Deus ou a Realidade última do universo." ${ }^{35}$ Knitter e Haight relativizam a salvação em Jesus Cristo a uma via normativa apenas para os cristãos. Geffré propõe conciliar um cristocentrismo constitutivo - e não apenas normativo - e um pluralismo inclusivo, que leva a sério os valores positivos e as sementes de verdade e de bondade presentes em outras tradições religiosas.

Não podemos confundir a universalidade do mistério de Cristo com a universalidade da religião cristã. "Só um aprofundamento do paradoxo da encarnação pode nos ajudar a respeitar essa diferença." ${ }^{36}$ Deve-se evitar identificar a contingência histórica de Jesus e o seu elemento crístico e divino. Para Geffré, "a manifestação do Absoluto de Deus na particularidade histórica de Jesus de Nazaré nos ajuda a compreender que a unicidade de Cristo não é exclusiva de outras manifestações de Deus na história." ${ }^{37}$ A identificação de Deus com Jesus nos remete "ao mistério inacessível de Deus que escapa a qualquer identificação." ${ }^{38} \mathrm{O}$ cristianismo não é exclusivo perante outras tradições religiosas. A partir do paradoxo da encarnação - da união do absolutamente universal com o absolutamente concreto - o cristianismo enquanto religião histórica se despe de toda absolutização e de todas as espécies de totalitarismos, verificando seu caráter relacional e dialogal.

Nenhum dos cristianismos históricos pode ter a pretensão de encarnar a essência do cristianismo como religião da revelação final sobre o mistério de Deus. Não se pode, portanto, confundir a universalidade de Cristo, como Verbo encarnado, e a universalidade do cristianismo como religião histórica. Ele é coexistente a toda a história. Em compensação, o cristianismo compartilha, nele mesmo, a relatividade de tudo o que é histórico. ${ }^{39}$

A revelação testemunhada pelo Novo Testamento "não esgota a plenitude das riquezas do mistério de Cristo, e é o próprio Jesus que insiste sobre a dimensão escatológica de sua mensagem.." ${ }^{\prime 0}$ No Evangelho de João,

$\begin{array}{ll}35 & \text { Id. Ibid., p. } 57 . \\ 36 & \text { Id. Ibid., p. } 58 . \\ 37 & \text { Id. loc. cit. } \\ 38 & \text { Id. loc. cit. } \\ 39 & \text { Id. Ibid., p. } 59 . \\ 40 & \text { Id. loc. cit. }\end{array}$


Jesus diz que "quando vier o Espírito da Verdade, ele vos guiará na verdade plena.” (Jo 16,13). É nesse sentido que Geffré afirma que "a verdade cristã não é nem exclusiva, nem mesmo inclusiva de qualquer outra verdade de ordem religiosa. Ela é singular e relativa à parte de verdade da qual as outras religiões são portadoras." ${ }^{41}$ A verdade e a bondade presente nas outras tradições religiosas podem expressar dimensões novas e diversas do Espírito de Cristo que atua na história e no coração das pessoas, não simplesmente no sentido de valores implicitamente cristãos, na lógica da preparação e do cumprimento. "É preferível falar de valores crísticos" ${ }^{4}$, ou seja, de um vínculo misterioso com a cristianidade ou cristicidade potencial de todo ser humano, criado como imago Christi.

Segundo Geffré, é na sua diferença que as religiões encontrarão seu cumprimento último e a sua plenitude em Jesus Cristo, mesmo que não encontrem a sua explicitação visível no cristianismo histórico. "Os teólogos deverão cada vez mais suportar, intelectualmente, o enigma de uma pluralidade de tradições religiosas na sua irredutível diferença." ${ }^{43}$ Não se trata de querer completar a revelação cristã a partir das verdades de outras tradições religiosas, mas de reconhecer a riqueza própria das doutrinas e práticas das outras religiões, para então procedermos a uma reinterpretação criativa da singularidade cristã. "Segundo a própria pedagogia de Deus na história da salvação, há uma função profética do estrangeiro para uma melhor inteligência da sua própria identidade." ${ }^{44}$ Outras experiências religiosas podem nos ajudar a conhecer mais amplamente o mistério de Deus que é sempre maior do que os conceitos que formulamos a seu respeito.

É preciso renunciar a uma teologia metafísica do Logos que afrouxa o vínculo entre o Verbo de Deus e o Jesus histórico. No centro da mensagem cristã está "a manifestação de Deus na particularidade histórica de Jesus de Nazaré" 45 , cuja unicidade singular se compreende não em termos de excelência e de integração, mas como relação. Ultrapassando toda espécie de imperialismo cristão, precisamos aprender a perceber o caráter relativo e dialógico do cristianismo. "A plenitude da revelação em Jesus Cristo não suprime a parte de verdade da qual as outras

\footnotetext{
41 Id. loc. cit.

42 Id. loc. cit.

43 Id. Ibid., p. 60.

44 Id. loc. cit.

45 Id. Ibid., p. 32.
} 
religiões podem ser portadoras na sua própria contingência histórica." ${ }^{\prime 46}$ Para isso, se deve acentuar o caráter escatológico da mensagem revelada, testemunhada por Jesus. Enquanto religião histórica, o cristianismo é ultrapassado pela própria mensagem que anuncia. Estamos à procura do Cristo desconhecido que nos espera em cada religião e em todo ser humano que busca viver o mistério divino.

Todo encontro nos provoca a aceitarmos o estatuto de nossa historicidade e a relativizarmos nossos esquemas de compreensão, avançando na inteligência da própria identidade a partir do confronto com a verdade do outro que desestabiliza e provoca a sair de nossa zona de conforto e ingressar em uma peregrinação em busca da verdade. Como religião da encarnação, o cristianismo é a religião da historicidade, da relatividade, pois apenas o Reinado de Deus é absoluto. "É o caráter original do cristianismo como religião da encarnação que funda sua natureza dialogal." ${ }^{\prime 77}$ Jesus como manifestação concreta do mistério absoluto é via de aproximação quenótica. A cruz de Jesus "é o símbolo de uma universalidade sempre ligada ao sacrifício de uma particularidade." ${ }^{\prime 4}$ Jesus morre em sua particularidade para ressuscitar como o Cristo universal. Essa dialética nos ajuda a repensar uma abertura ao outro, articulando a universalidade da mensagem cristã com a pluralidade das tradições religiosas e culturais, e a perceber que a pretensão à universalidade do cristianismo não se verifica historicamente.

Para manifestar o caráter não imperialista do cristianismo e, portanto, favorecer o diálogo inter-religioso, creio preferivel voltar ao próprio centro da fé cristã, isto é, ao mistério da Encarnação no seu sentido mais realista e não mítico. [...] Trata-se de desenrolar todas as implicações do mistério de Cristo considerado como Universal concreto. [...] Jesus nos revelou o amor universal de Deus por todos [...] em sua humanidade concreta e por meio dela. Essa identificação de Deus com a realidade transcendente a partir da humanidade concreta de Jesus de Nazaré éo traço distintivo do cristianismo. ${ }^{49}$

O cristianismo é a revelação da transcendência divina a partir da imanência jesuânica. A consciência de que a humanidade de Jesus é uma tradução inadequada da plenitude do mistério de Cristo, nos insere na dinâmica da

\begin{tabular}{ll}
\hline 46 & Id. loc. cit. \\
47 & Id. Ibid., p. 38. \\
48 & Id. Ibid., p. 40. \\
49 & Id. Ibid., p. 129-130.
\end{tabular}


economia do Verbo encarnado como sacramento de uma economia mais ampla. Jesus remete ao Deus transcendente, para além de toda identificação, o totalmente Outro. O paradoxo da presença do Absoluto na contingência histórica nos convida a não absolutizar o cristianismo e a buscar uma verdade mais plena no diálogo entre as religiões. Em referência à kênosis de Cristo (Fl2,6-8), o cristianismo toma consciência de seus limites e pode exorcizar de seu interior toda pretensão totalitária. O princípio quenótico de limitação é advento de possibilidade dialógica e relacional.

\section{O diálogo entre as religiões na perspectiva da alteridade irredutível}

A questão do diálogo entre as religiões apresenta-se como um desafio importante e imprescindível para o bem de nosso planeta. "Diante de uma realidade caracterizada pelo pluralismo religioso, não há mais condições de uma perspectiva de entrincheiramento, de fixação num único itinerário, sem se dar conta da singularidade e da riqueza de outros caminhos." ${ }^{\circ 0}$ A abertura à relação com o outro, reconhecendo-o em sua alteridade e diferença irredutíveis à minha identidade, precisam ser vistos não como uma ameaça, mas como uma beleza que se manifesta na diversidade, cuja pluralidade de singularidades edifica a todos. "Identidade e alteridade não se excluem; antes, se conjugam." ${ }^{51} \mathrm{O}$ encontro com o outro é condição de possibilidade para a afirmação saudável da própria identidade.

Vivemos em uma época planetária. A consciência de habitarmos em uma "casa comum" 52 deveria ser motivo para superarmos as divergências de raças, de culturas e de religiões. No que tange às religiões,

50 TEIXEIRA, Faustino. op. cit., p. 188.

51 Id. Ibid., p. 189.

52 Na encíclica Laudato Si' sobre o cuidado da casa comum, o Papa Francisco chama a atenção para o fato de que "a maior parte dos habitantes do planeta declara-se crente, e isto deveria levar as religiões a estabelecer diálogo entre si, visando o cuidado da natureza, a defesa dos pobres, a construção de uma trama de respeito e fraternidade" (LS 201). As religiões têm grandes motivos para estabelecerem diálogo na busca da paz, superando os particularismos estreitos que dividem, na perspectiva mais universal da edificação do bem comum. Segundo Geffré, as religiões ajudam as pessoas a discernir entre o bem e o mal e a compreender o humano verdadeiro. "É vocação permanente das grandes tradições religiosas da humanidade serem instâncias de sabedoria que lembram que o homem não se define somente pelo lucro, pela manipulação da natureza e da vida, pela conquista do espaço. Ele deve também fazer a aprendizagem da gratuidade, do amor e da amizade, da cultura e da criação estética, do silêncio e da meditação." (GEFFRÉ, Claude. op. cit., p. 24). 
o que une deveria ser mais importante do que o que separa. Apesar de buscarem o absoluto, todas as religiões inserem-se no interior do estatuto da relatividade histórica. De acordo com Geffré, "não haverá paz civil, nem paz mundial, sem paz entre as religiões." ${ }_{53}$ As religiões precisam compreender a sua responsabilidade histórica a serviço da vida e da convivência humana. As atitudes antiéticas realizadas em nome da religião são revoltantes para a consciência humana universal.

Na aurora do século XXI, em cada religião há homens e mulheres que estão dispostos a ultrapassar suas querelas ancestrais, a renunciar à sua vontade de conquista e de dominação para se pôr a serviço do homem. Eis ai um sinal dos tempos. Em Assis, em 1986, as autoridades religiosas mais respeitadas do mundo se encontraram como mensageiros de paz. Em contraste com essa vontade de diálogo, o renascimento de fanatismos e de integrismos assume um caráter escandaloso. ${ }^{54}$

Segundo Geffré, há algumas condições para um verdadeiro diálogo. ${ }^{55}$ Primeiro, é preciso respeitar o outro na sua diferença, estar aberto às suas ideias e convicções, procurar "ultrapassar os preconceitos espontâneos." ${ }_{56}$ A atitude primordial é a empatia, não reduzindo a perspectiva do outro ao já sabido, apenas pelo fato de carregar semelhanças com ideias já preconcebidas. Cada religião e cada experiência religiosa carregam elementos que só podem ser compreendidos em referência a uma totalidade identitária. Nesse sentido, Geffré alerta sobre a necessidade de cultivar "o senso de uma hermenêutica da diferença e não uma

53 Id. Ibid., p. 15. Segundo Hans Küng, não haverá sobrevivência do mundo sem a paz entre as religiões. "Não haverá paz entre as nações, se não existir paz entre as religiões. Não haverá paz entre as religiões, se não existir diálogo entre as religiões. Não haverá diálogo entre as religiões, se não existirem padrões éticos globais." (KÜNG, Hans. Religiões do mundo, p. 280). Para Küng, as religiões, na medida em que fomentam um autêntico humanismo, têm uma importante contribuição para a fundamentação de um ethos mundial para a sobrevivência do planeta.

54 GEFFRÉ, Claude. op. cit., p. 23.

55 De acordo com Geffré, "o diálogo inter-religioso não escapa às regras de qualquer diálogo autêntico" (Id. Ibid., p. 120), o qual inclui respeito pelas diferenças, fidelidade às próprias conviç̧ões, em uma defesa argumentada da verdade que não prescinda de uma igualdade reconhecida entre os parceiros. Em todo diálogo há uma "dissimetria fundamental" (Id. Ibid., p. 123), ou seja, uma irredutibilidade das identidades envolvidas no embate. Todo diálogo requer disposição para ir ao encontro do outro. No relacionamento dialógico, as diferenças são um fator de inestimável enriquecimento mútuo quando há empatia e alteridade.

56 Id. Ibid., p. 16. 
lógica que leva à pura assimilação." ${ }^{57}$ Para além do semelhante, é preciso compreender o diferente na sua alteridade.

A segunda condição para o diálogo é "permanecer fiel a si mesmo." ${ }^{158}$ No diálogo, assim como na dinâmica do olhar, sempre se parte de um ponto, de uma referência, ou seja, todo ponto de vista é sempre o olhar a partir de um ponto específico. Geffré diz que "é uma ilusão pensar que, para facilitar o diálogo religioso, é preciso pôr a sua fé religiosa entre parênteses ou suspendê-la provisoriamente." ${ }^{59}$ É a partir do próprio engajamento pessoal que cada interlocutor vai estabelecer uma relação dialógica, sempre respeitando as convicções alheias. Apenas assim, o diálogo irá conduzir genuinamente a uma inteligência mais apurada da própria identidade e à celebração de uma verdade mais elevada que as perspectivas iniciais unilaterais.

Como terceira condição de possibilidade para o diálogo, Geffré enfatiza a necessidade de estabelecer "uma base comum, um critério comum, sobre o qual os parceiros possam se pôr de acordo." ${ }^{60}$ Algo que ajude a buscar a unidade na diversidade, seja na ordem doutrinal: o reconhecimento comum do Deus único pelas religiões monoteístas; na ordem ética: a busca de um humanismo autêntico reconhecido pela consciência humana universal; na ordem psicológica: a descentração de si em benefício de uma Realidade última; na ordem antropológica: a universalidade do homo religiosus; ou na ordem da fé fundamental das religiões, distinta das crenças particulares. É preciso discernimento, pois há o perigo desse critério comum postular uma essência da religião desencarnada de sua realização histórica.

Apesar da possibilidade de discernir um fundo comum como possibilidade de coexistência dialogal inter-religiosa, "acima da diversidade irredutível dos fenômenos religiosos"61 , não há diálogo entre as religiões no abstrato. Trata-se sempre do diálogo entre religiões específicas e concretas. Também seria ilusão e até uma injustiça pensar em uma

\footnotetext{
57 Id. loc. cit.

58 Id. loc. cit.

59 Id. loc. cit. Nessa mesma linha, Jacques Dupuis afirma que "a autenticidade do diálogo não autoriza a colocar entre parênteses a própria fé nem mesmo provisoriamente" (DUPUIS, Jacques. Rumo a uma teologia cristã do pluralismo religioso, p. 515), pois um diálogo autêntico não busca o sincretismo, mas almeja um terreno comum como plataforma de compreensão mútua.

60 GEFFRÉ, Claude. op. cit., p. 16.

61 Id. Ibid., p. 18.
} 
democracia inter-religiosa na qual todas as religiões seriam equivalentes. Podemos sim elaborar uma visão comparativa e até mesmo falar em uma misteriosa complementaridade entre as religiões, sempre tendo presente a alteridade irredutível de cada identidade.

\section{Conclusão}

O pluralismo cultural e religioso hodierno nos convida a reinterpretar algumas das verdades fundamentais do cristianismo a partir da experiência histórica contemporânea ${ }^{62}$, que concilia ao mesmo tempo secularização, ateísmo, indiferença religiosa, retorno ao religioso e concepções religiosas que divergem da Escritura. O diálogo ecumênico ajudou a quebrar uma postura católica absolutista, hegemônica e eclesiocêntrica. A partir do Concílio Vaticano II, o magistério eclesiástico emite um julgamento positivo sobre as outras confissões religiosas, assumindo uma postura dialógica. A teologia é chamada a reinterpretar a unicidade do cristianismo, superando a ideia triunfalista cristã sobre as outras religiões, para expressar de forma criativa e não violenta a sua identidade peculiar em meio a uma pluralidade de narrativas teológicas, as quais possuem um alcance hermenêutico relevante na leitura dos arquétipos antropológicos, culturais e religiosos, que estão no substrato dos estados de consciência hodiernos.

Interrogar-se a respeito do significado da pluralidade de expressões religiosas no interior do único desígnio divino universal requer uma postura

62 Um texto clássico manifesta uma pluralidade de sentidos que resiste a uma interpretação definitiva. Independente de sua origem cultural, tem um alcance universal na comunidade humana. A teologia confronta-se com textos fundadores entre os quais vigoram também interpretações tradicionais do cristianismo. $\mathrm{E}$ apesar da variedade de interpretações, a mensagem cristã resiste na sua essência a uma interpretação definitiva. Há sempre um contexto histórico e cultural que nos precede, como um horizonte de interpretação, e que podemos denominar de tradição. "Uma das tarefas da hermenêutica é discernir os elementos fundamentais da experiência cristã e dissociá-los das linguagens nas quais esta experiência foi traduzida" (Id. Crer e interpretar, p. 37), para interpretá-los a partir de nossa situação histórica atual. A revelação cristã é antes de tudo uma experiência de fé que suscitou testemunhos e se tornou uma mensagem traduzida em uma pluralidade de linguagens. A riqueza do conteúdo da experiência acaba por se disseminar em uma multiplicidade de formas de expressão. A experiência fontal da comunidade cristã primitiva é uma interpretação dos fatos fundadores, e os testemunhos posteriores serão interpretação das interpretações primordiais. A missão da teologia é atualizar e tornar pertinente para a contemporaneidade a mensagem da revelação cristã. (Cf. GOMES, Tiago de Fraga. $A$ teologia hermenêutica de Claude Geffré e a sua relevância para a teologia da revelação, p. 13). Geffré busca uma nova compreensão das fontes escriturísticas, distanciando-se tanto dos preconceitos positivistas de uma objetividade textual, quanto de um romantismo que professa a congenialidade entre o leitor de hoje e o autor do passado. 
de respeito pela experiência do outro e de sinceridade na busca da verdade. $\mathrm{O}$ horizonte do diálogo inter-religioso nos leva a reinterpretar muitas de nossas verdades de fé a respeito da salvação e do conhecimento do mistério de Deus, mas também nos leva a ter humildade diante de um mistério que não podemos abarcar com a nossa racionalidade e com as nossas experiências limitadas. "Os cristãos são, por pura graça, as testemunhas da Revelação que lhes foi confiada por Jesus Cristo, mas não são seus proprietários." ${ }^{63}$ Somos crentes, porém, não podemos ter a pretensão de ser donos de Deus. O diálogo nos insere numa tensão que interroga e desapropria a nossa fé pessoal de todo egocentrismo e a provoca a aprofundar a sua autocompreensão. No diálogo com outras religiões, toda tentativa de dominação alheia acaba desmascarada como soberba e prepotência. "O Absoluto corresponde somente a Deus; o que cabe ao homem é a tarefa inacabável de ir assimilando-o." ${ }^{64}$ Segundo Geffré, "é vocação dos cristãos anunciar a todas as pessoas que a salvação de Deus veio em Jesus Cristo, respeitando os caminhos misteriosos de Deus no coração de cada uma" ${ }^{65}$, pois Deus quer se revelar e salvar a todos.

Seguir Cristo na atualidade é um desafio que exige criatividade. Não podemos estar alheios aos desafios que o mundo nos apresenta. Além disso, ser cristão não é simplesmente proceder a uma imitação mecânica do que Cristo fez no passado. "O cristão não está, pois, condenado ao ideal impossível de reproduzir o que Cristo fez. Ao contrário, ele está entregue à sua consciência, iluminada pelo Espírito, para inventar o que Cristo faria hoje." ${ }^{66}$ E o que Cristo faria hoje diante de um mundo que se tornou tão diverso e ao mesmo tempo tão carente de diálogo e de compreensão entre as pessoas das diversas tradições religiosas?

\section{Referências}

BÍBLIA. Português. A Bíblia de Jerusalém. Nova edição rev. e ampl. São Paulo: Paulus, 2002.

DOCUMENTOS DO CONCÍLIO ECUMÊNICO VATICANO II (19621965). 4. ed. Trad. Tipografia Poliglota Vaticana. São Paulo: Paulus, 2007 (Documentos da Igreja).

\footnotetext{
63 GEFFRÉ, Claude. De Babel a Pentecostes, p. 61.

64 QUEIRUGA, Andrés Torres. O diálogo das religiões, p. 22.

65 GEFFRÉ, Claude. Crer e interpretar, p. 180.

66 Id. Como fazer teologia hoje, p. 270.
} 
DUPUIS, Jacques. Rumo a uma teologia cristã do pluralismo religioso. Trad. Márcia de Almeida; Euclides Martins Balancin. São Paulo: Paulinas, 1999 (Pensamento Teológico).

DUQUOC, Christian. A teologia no exílio: o desafio da sobrevivência da teologia na cultura contemporânea. Trad. Gentil Adelino Titton. Petrópolis: Vozes, 2006.

FRANCISCO. Carta Encíclica Laudato Si': sobre o cuidado da casa comum. São Paulo: Paulus; Loyola, 2015 (Documentos do Magistério).

GEFFRÉ, Claude. Como fazer teologia hoje: hermenêutica teológica. Trad. Benôni Lemos. São Paulo: Paulinas, 1989 (Teologia Hoje).

. Crer e interpretar: a virada hermenêutica da teologia. Trad. Lúcia M. Endlich Orth. Petrópolis: Vozes, 2004.

. De Babel a Pentecostes: ensaios de teologia inter-religiosa. Trad. Margarida Maria Cichelli Oliva. São Paulo: Paulus, 2013 (Dialogar).

GOMES, Tiago de Fraga. A teologia hermenêutica de Claude Geffré e a sua relevância para a teologia da revelação. 2015. 140 f. Dissertação (Mestrado em Teologia) - Faculdade de Teologia, Pontifícia Universidade Católica do Rio Grande do Sul, Porto Alegre, 2015.

KÜNG, Hans. Religiões do mundo: em busca dos pontos comuns. Trad. Carlos Almeida Pereira. Campinas: Verus, 2004.

PANASIEWCZ, Roberlei. Diálogo e revelação: rumo ao encontro interreligioso. Belo Horizonte: C/ Arte, 1999.

QUEIRUGA, Andrés Torres. O diálogo das religiões. Trad. Paulo Bazaglia. São Paulo: Paulus, 1997 (Comunidade e Missão).

TEIXEIRA, Faustino. Teologia das religiões: uma visão panorâmica. São Paulo: Paulinas, 1995 (Caminhos de Diálogo).

E-mail do Autor: tiago_mail@yahoo.com.br 